\title{
PRE-NOSOLOGICAL MONITORING OF THE HEALTH STATUSES OF FEMALE OBSTETRICIAN-GYNECOLOGISTS
}

\section{WSTĘPNE MONITOROWANIE NOZOLOGICZNE STANU ZDROWIA KOBIET BĘDĄCYCH LEKARZAMI POŁOŻNIKAMI-GINEKOLOGAMI}

\author{
Alena Lisok ${ }^{1(A, B, C, D, E, F)}$, Igor Naumov ${ }^{1(A, D)}$, Anastasia Pavliukovets $^{2(B, D)}$, \\ Sergey Makarov $^{3(B, D)}$, Larisa Svistunovich ${ }^{3(B, D)}$ \\ ${ }^{1}$ Department of General Hygiene and Ecology, Grodno State Medical University, Belarus \\ ${ }^{2}$ Department of Microbiology, Virology and Immunology named after S.I. Gelberg, \\ Grodno State Medical University, Belarus \\ ${ }^{3}$ Centralized Cytological Laboratory, Grodno Regional Clinical Hospital, Belarus
}

Authors' contribution Wkład autorów:

A. Study design/planning B. Data collection/entry zebranie danych C. Data analysis/statistics dane - analiza i statystyki D. Data interpretation interpretacja danych E. Preparation of manuscript przygotowanie artykułu F. Literature analysis/search wyszukiwanie i analiza literatury G. Funds collection zebranie funduszy zaplanowanie badań

\section{Summary}

Background. Female obstetrician-gynecologists of reproductive age provide medical care in harmful working conditions creating health risks for themselves.

Material and methods. Female obstetrician-gynecologists working in hospitals $(n=32)$ and antenatal clinics $(n=32)$, therapists of outpatient clinics $(n=31)$ and women working in the positions of accountants, economists, lawyers and secretaries $(n=31)$ in the healthcare organizations of the Grodno region participated in this research. Working conditions were assessed by studying the results of the workplaces' certification. Pre-nosological monitoring was conducted using the following methods: cytomorphological testing of buccal epithelium, microbiological testing of the oral biocenosis and psychological testing.

Results. We established that the studied female obstetrician-gynecologists work in harmful conditions (hazard classes 3.2-3.3). It was associated with functional changes in their bodies: $23.3 \%$ of them had deviations in cytomorphological parameters of buccal epithelium; $59.3 \%$ had excessive amounts of $E$. coli group bacteria in their oral cavity and already formed phases of the occupational burnout syndrome.

Conclusions. The selected set of methods for pre-nosological monitoring permit analysis of the impact of different occupational factors and the formation of target risk groups for the implementation of measures improving adaptive reserves.

Keywords: occupational conditions, health risks, female doctors, pre-nosological monitoring

\section{Streszczenie}

Wprowadzenie. Lekarki położne-ginekolodzy $\mathrm{w}$ wieku rozrodczym świadczą opiekę medyczną w szkodliwych warunkach pracy, które stanowią ryzyko dla ich zdrowia.

Materiał i metody. W badaniu brały udział lekarki położne-ginekolodzy, pracujące w szpitalach $(n=32)$ i placówkach opieki przedporodowej $(n=32)$, terapeutki pracujące w przychodniach $(n=31)$ oraz kobiety, które pracowały na stanowiskach księgowych, ekonomistów, prawników i sekretarek $(n=31)$ w placówkach opieki zdrowotnej obwodu grodzieńskiego. Warunki pracy były oceniane poprzez badanie wyników certyfikacji miejsc pracy. Wstępne monitorowanie nozologiczne przeprowadzono następującymi metodami: badanie cytomorfologiczne nabłonka policzka, badanie mikrobiologiczne biocenozy jamy ustnej oraz badania psychologiczne.

Wyniki. Ustalono, że lekarki położne-ginekolodzy pracowały w szkodliwych warunkach (klasy zagrożenia 3.2-3.3). Wiązało się to ze zmianami w funkcjonowaniu organizmu kobiet: u 23,3\% z nich stwierdzono nieprawidłowości w parametrach cytomorfologicznych nabłonka policzka, u 59,3\% stwierdzono zbyt wysokie wartości bakterii z grupy E. coli w jamie ustnej i już ukształtowane fazy syndromu wypalenia zawodowego.

Wnioski. Wybrany zestaw metod wstępnego monitorowania nozologicznego pozwala zidentyfikować wpływ różnych czynników zawodowych i stworzyć docelowe grupy ryzyka w celu wdrożenia środków zapobiegawczych, które zwiększą rezerwy adaptacyjne organizmu.

Figures: 4

References: 15

Submitted: 2018 Aug 28

Accepted: 2019 Sep 23
Słowa kluczowe: warunki pracy, ryzyko dla zdrowia, kobiety lekarze, wstępne monitorowanie nozologiczne 


\section{Introduction}

Female obstetrician-gynecologists of reproductive age belong to the risk group for health deterioration due to a complex interaction of harmful occupational factors [1]. However, these women are often at the pre-nosological stage of the disease with reversible functional disorders that are prospective in terms of correction [2]. Nevertheless, evaluation and identification of the pre-nosological conditions characterized by a predominance of nonspecific changes in the body is quite a difficult task in the case of classical clinical approach usage [3].

It is for this reason that the introduction of pre-nosological monitoring system for assessment of worker health status is very topical, especially because of the lengthening trend for the asymptomatic period of occupational-related diseases in recent years [4]. The most promising methods of this kind are those based on the study of various parameters of the oral mucosa, found to be the earliest target for exposure of aggressive factors and psychological testing. These allow assessment of the body's functional state in a constantly changing environment $[5,6]$.

The purpose of this study was to assess the health status of female obstetrician-gynecologists of reproductive age by applying pre-nosological diagnostic methods.

\section{Material and methods}

This research was carried out by the Department of General Hygiene and Ecology at the Grodno State Medical University from 2015-2018 (Governmental registration number 20150651 of $18^{\text {th }}$ May 2015). The research protocol was approved by the Bioethical Commissions of the Grodno State Medical University and healthcare organizations of the Grodno region where the research was conducted. Groups of surveyed women were formed after prior consultation and written informed consent.

We chose healthy women to participate in the research on the basis of their medical examination results. Participation was disallowed in the context of health complaints, periods of convalescence, or use of antibacterial, anti-inflammatory and hormonal drugs on the eve of the examination. The main group consisted of female obstetrician-gynecologists providing medical care in obstetric-gynecological departments of hospitals (the first subgroup, $n=32$ ) and antenatal clinics (the second subgroup, $n=32$ ). The control group consisted of female doctor therapists who worked in outpatient clinics $(n=31)$. Women with higher education who worked in healthcare organizations in the positions of accountants, economists, lawyers and secretaries ( $n=31)$ were included in the comparison group. All examined women lived in the Grodno region of the Republic of Belarus.

Hygienic analysis of the working conditions was carried out using the latest workplace certifications, as well as on the basis of measurements made by the laboratory service of the Grodno Regional Center of Hygiene, Epidemiology and Public Health.

Pre-nosologicalmonitoring of the health status was conducted using the following methods: cytomorphological testing of the buccal epithelium for assessment of the influence of occupational factors of biological nature, microbiological testing of the oral biocenosis for assessment of the influence of occupational factors of chemical nature and psychological testing for assessment of mental tension.

Cytomorphological testing of the buccal epithelium was aimed at identifying anomalously changed cells in the form of degenerated neutrophilic leukocytes, mastocytes, non-nuclear cells, epitheliocytes with micronuclei, protrusions, doubled nuclei, double nuclei, phagocytized apoptotic bodies, cells in the state of karyorexis and vacuolar dystrophy [7]. Microbiological testing of the oral biocenosis was aimed at identifying E. coli group bacteria normally absent from the mucous membrane due to cellular secreted immune factors [8]. Psychological testing was conducted to identify the main symptoms of occupational burnout syndrome using the method described by Boyko in "Diagnostics of person's emotional burnout" [9].

Statistical processing of the data was performed using Statistica 10.0. The normal distribution of quantitative traits was estimated using Kolmogorov-Smirnov agreement criterion (the data are presented as $M \pm \delta$ in the case of the normal distribution and the statistical significance of the differences was determined using the t-criterion). Conjugation tables were created to assess qualitative characteristics: the hypothesis of independence of columns and rows was tested using the Fisher exact test, the Pearson $\chi^{2}$ test, the Kruskal-Wallis test, the trend criterion for Alvo and Berthelot shares; $\tau$ Goodman and Kruskal criterion were used as the association coefficients. In all analyzed cases, the null hypothesis was rejected at a value of $\mathrm{p}<0.05$.

\section{Results}

It was found that female doctors of the first subgroup of the main group were the most exposed to occupational factors. The greatest contributions to the formation of the final evaluation of their working conditions (hazard 
class 3.3) were made by high mental tension (hazard class 3.2), factors of biological (hazard class 3.2) and chemical (hazard class 3.1) nature. Harmful working conditions at the workplaces of female doctors of the second subgroup of the main group (class 3.2) consisted of biological factors' influence (class 3.2) and high mental tension while diagnosis and treatment process were one degree lower (class 3.1).

The high mental tension of work was due to significant intellectual (solving complex production problems in limited time, processing large amounts of complexity with subsequent distribution of other functions), emotional (increased responsibility for the results of medical care and patient safety) and sensory loads (long focused observation) coupled with double shift irregular work regimes, as well as a high working day density (up to $90.3 \%$ of the work shift).

Occupational factors of a biological nature posed a threat due to prolonged contact (more than $80 \%$ of working time) with microorganisms of different pathogenicity groups (viruses such as hepatitis B and D, human immunodeficiency, influenza, herpes; bacteria including pathogens of gonorrhea, syphilis, local inflammatory processes; fungi including pathogens of candidiasis; protozoa including pathogens of urogenital trichomoniasis), including their hospital strains, despite the relatively low rates of total air bacterial contamination in the working area (up to $485.1 \pm 99.1 \mathrm{cfu} / \mathrm{m}^{3}$ ).

The impact of chemical occupational factors was due to constant long-term contact with vapors and aerosols of chemical toxicants of different hazard classes (drugs, disinfectants, ethyl and isopropyl alcohols, hydrogen peroxide and narcotic anesthetics, ozone) in total concentrations exceeding maximal permissible values (4 points on the Wright's scale).

Professional activity of female therapists (control group) was linked mainly to the unfavorable effects of biological occupational factors (hazard class 3.2). Women of the comparison group worked in permissible working conditions (class 2) without the influence of any harmful occupational factors. Study of the subjects' smears revealed only four variants of cytomorphological changes in buccal epithelium cells from all possible changes: degenerated neutrophilic leukocytes, epitheliocytes with doubled nucleus, epitheliocytes with double nucleus, and epitheliocytes with protrusion in the shape of the tongue.

We found that the combination of harmful occupational factors was associated with more expressed changes in the functional states of female obstetrician-gynecologists of reproductive age performing professional duties in the hospitals. Thus, the number of identified degenerated neutrophilic leukocytes (median $=4$, interquartile range $=0-10)$ was significantly higher than in those of the second subgroup $(\mathrm{p}<0.01)$ and control $(\mathrm{p}<0.001)$ group (Figure 1).

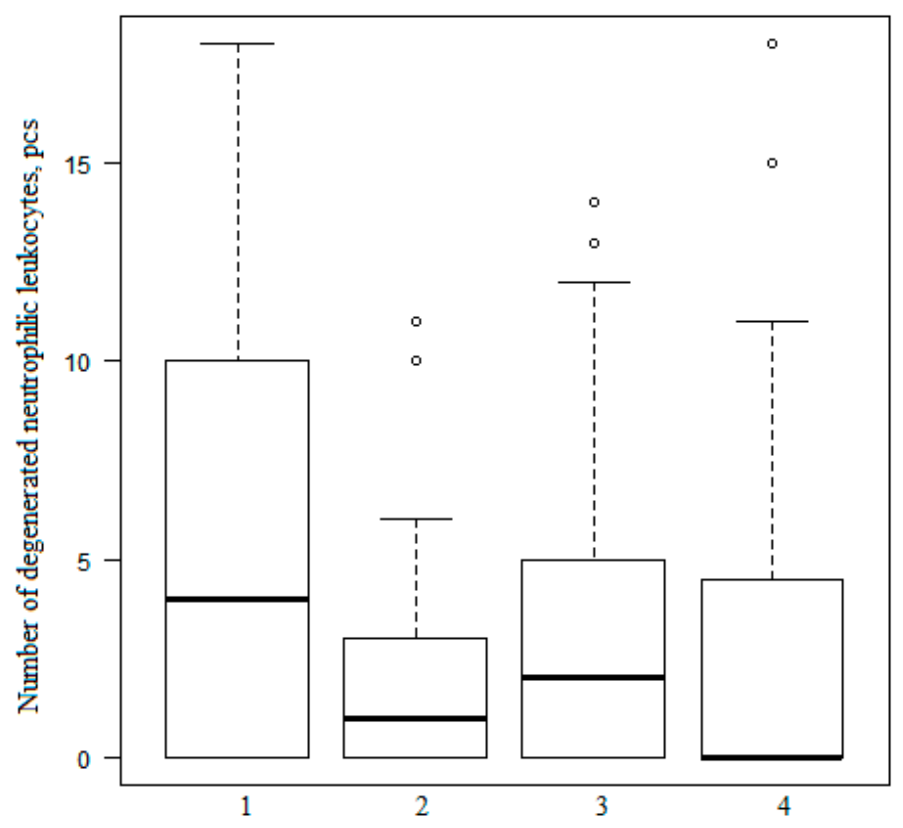

1 - obstetrician-gynecologists of hospitals; 2 - obstetrician-gynecologists of antenatal clinics; 3 - therapists of outpatient clinics; 4 - women with higher education who worked in the positions of accountants, economists, lawyers and secretaries in the healthcare organizations

Figure 1. Number of degenerated neutrophilic leukocytes in the buccal epithelium smears taken from women who worked in the healthcare organizations 
The buccal epithelial cells of female obstetrician-gynecologists who provided medical care in antenatal clinics were mainly represented by unchanged forms (median=98, interquartile range=96-99), evidence of more stable adaptive functioning. Nevertheless, we found that $80.6 \%$ of them had all the above-described variants of cytomorphological changes of the buccal epithelium in the smears. In addition, the frequency of epithelial cells with protrusions in the shape of the tongue taken from women of this subgroup was significantly higher than those of obstetrician-gynecologists of the first subgroup $(\mathrm{p}<0.00001)$, therapists $(\mathrm{p}<0.01)$, as well as women from the comparison group $(\mathrm{p}<0.00001)$.

The absence of a marked effect of harmful chemical factors, as well as the performance of professional duties in the permissible parameters of physical and mental tension of the labor process resulted in the stability of the adaptation's processes among female therapists: unchanged cytomorphological cells prevailed in the smears of buccal epithelium (median=97, interquartile range=94-98). However, we found degenerated neutrophilic leukocytes, epitheliocytes with doubled and double nuclei, as well as with protrusions in the shape of the tongue prevailed quantitatively in the smears taken from female therapists compared to obstetrician-gynecologists of inpatient hospitals $(\mathrm{p}<0.001)$ and women in the control group $(\mathrm{p}<0.00001)$.

Adaptation reserves of the women from the comparison group were the highest: smears of $64.5 \%$ women were represented by unchanged forms of buccal epitheliocytes. We have found only degenerated neutrophilic leukocytes from all possible cytomorphological changes in the smears of women from the control group. Although these morphological elements were identified in 35.4\% of women, their frequency in the smears was significantly lower compared to those of the first subgroups of the main group $(70.0 \%, p<0.01)$ and the control group $(70.9 \%, \mathrm{p}<0.005)$. Only $6.4 \%$ of women had deviations from the reference values in the content of degenerated neutrophilic leukocytes.

The microbiological study also confirmed that the professional activity in the conditions of the highest hazard classes was accompanied with the greatest changes in the functional state of the women's bodies of the first and the second subgroups of the main group: the percentage shares of examined subjects, who had excessive values of $E$. coli group bacteria, were, respectively, $59.3 \%$ and $43.7 \%$ (Figure 2).

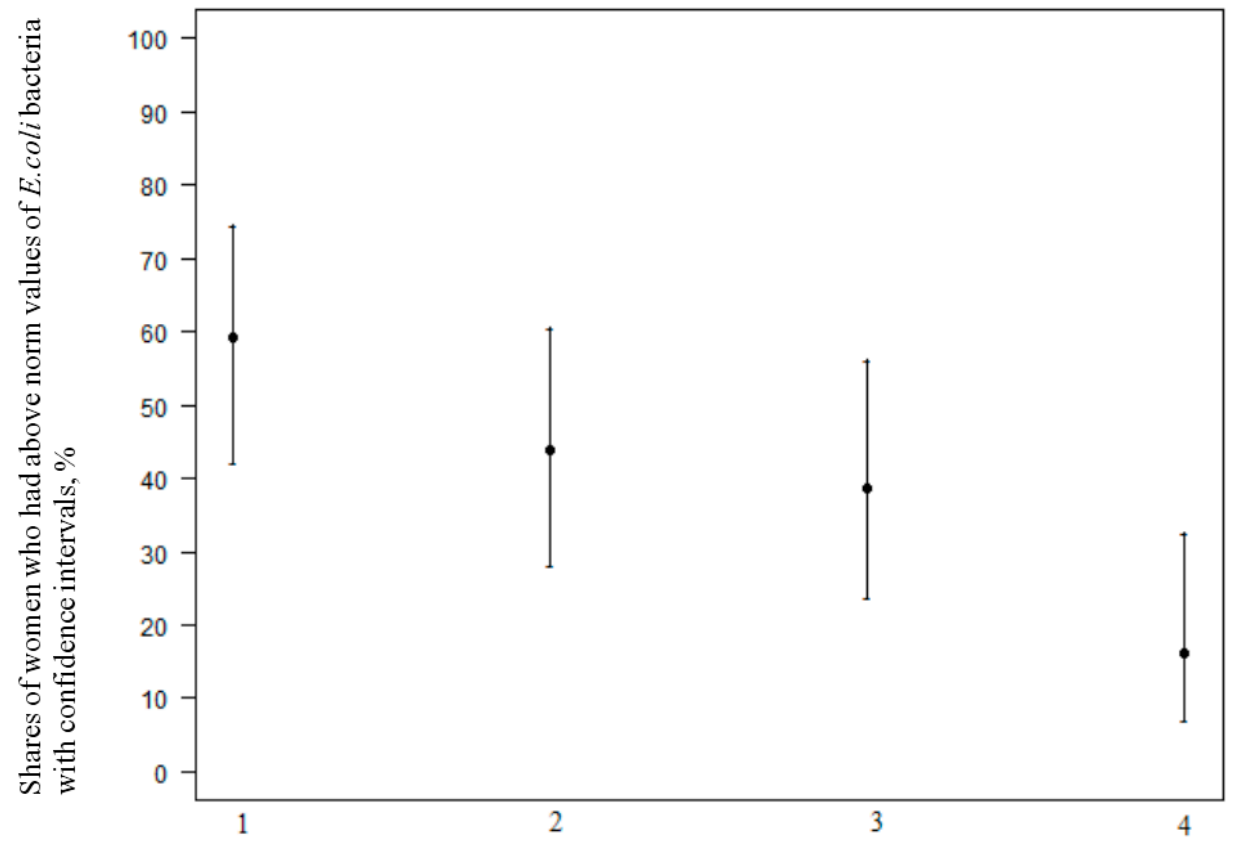

1 - obstetrician-gynecologists of hospitals; 2 - obstetrician-gynecologists of antenatal clinics; 3 - therapists of outpatient clinics; 4 - women with higher education who worked as accountants, economists, lawyers and secretaries in the healthcare organizations

Figure 2. Shares of women with confidence intervals who had above-norm values of $E$. coli group bacteria

The adaptation potential of female therapists was slightly higher: excessive values of the E. coli group bacteria were identified only among $38.7 \%$ of women. In turn, the percentage share of women in the control group who worked in permissible working conditions and had excessive values of E. coli group bacteria was the smallest (only 16.1\%), that is an objective evidence of the stable functioning of adaptation mechanisms in a large majority of the examined women (Figure 3). Therefore, in spite of the fact that the greatest differences in 
the quantitative values of the parameters were registered between the examined women of the first subgroup of the main group and the women of the comparison group $(\mathrm{p}<0.001)$, they were also significant between the obstetrician-gynecologists of inpatient hospitals and therapists of outpatient clinics $(\mathrm{p}<0.05)$. In addition, we identified significant differences in the values of the quantitative parameters of the $E$. coli group bacteria during the examination of women from the second subgroup of the main group and women of the control group $(p<0.01)$. A significant majority of female doctors of the first $(59.3 \pm 0.86 \%)$ and second $(46.8 \pm 0.88 \%)$ subgroups of the main group had already formed phases of the occupational burnout syndrome in comparison to examined women of the comparison group (25.8 $\pm 0.76 \%$; $<<0.05)$ (Figure 3).

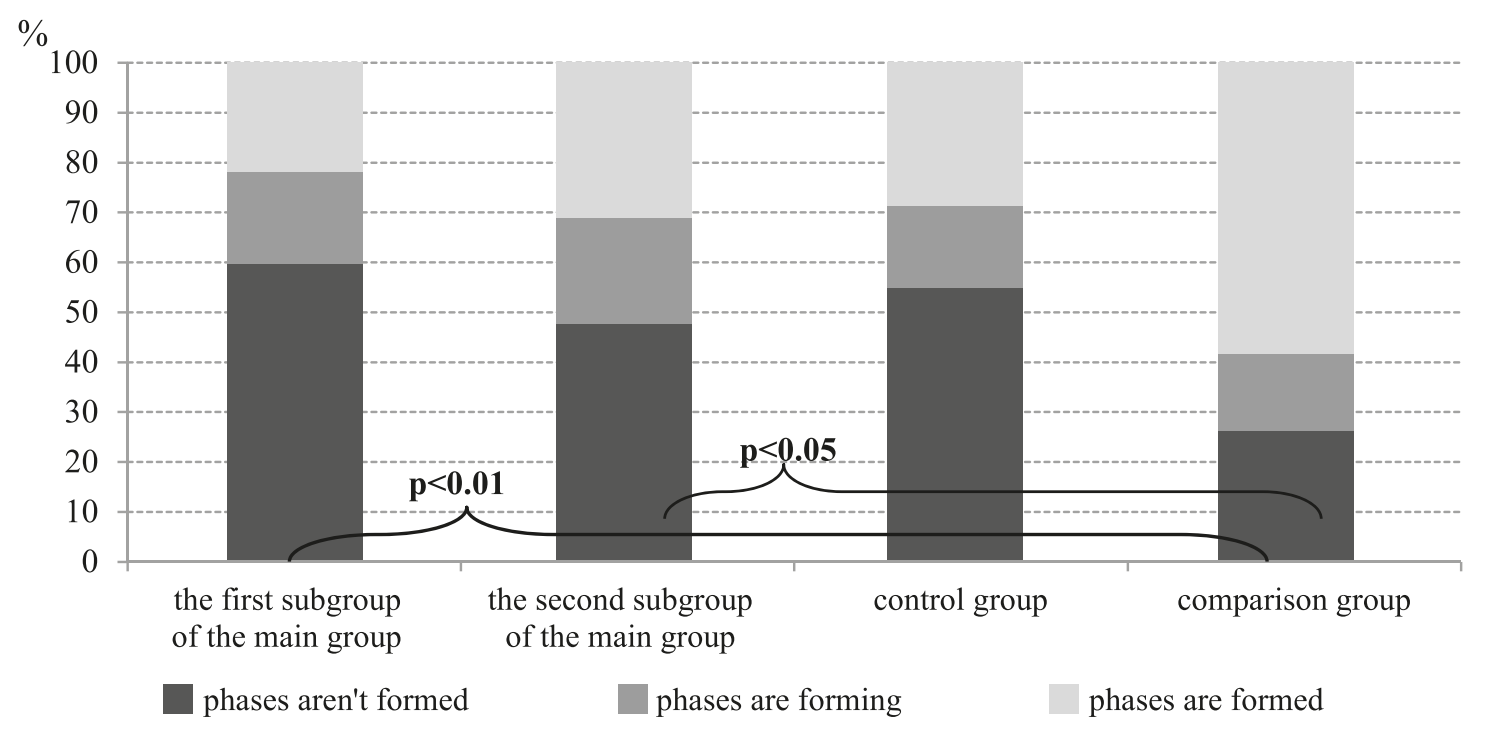

Figure 3. Results of the psychological testing for identification of the occupational burnout syndrome among examined women $(\%)$

A significant majority of the examined women who had only one formed phase of the occupational burnout syndrome, whereas all phases of this syndrome were completely formed only in $10.4 \pm 0.68 \%$ of obstetriciangynecologists who provided medical care in the hospitals and in $5.8 \pm 0.52 \%$ of women from the control group.

Analysis of the structure of the occupational burnout syndrome's phases with a completed single-phase formation cycle made it possible to establish that the vast majority of women from the first and second subgroups of the main group were in the phase of "resistance" (62.0 $11.34 \%$ and $60.0 \pm 1.54 \%$, respectively), $22.8 \pm 1.14 \%$ and $30.0 \pm 2.64 \%$ in the phase of "depletion", and $15.2 \pm 0.99 \%$ and $10.0 \pm 0.94 \%$ in the phase of "tension" (Figure 4 ).

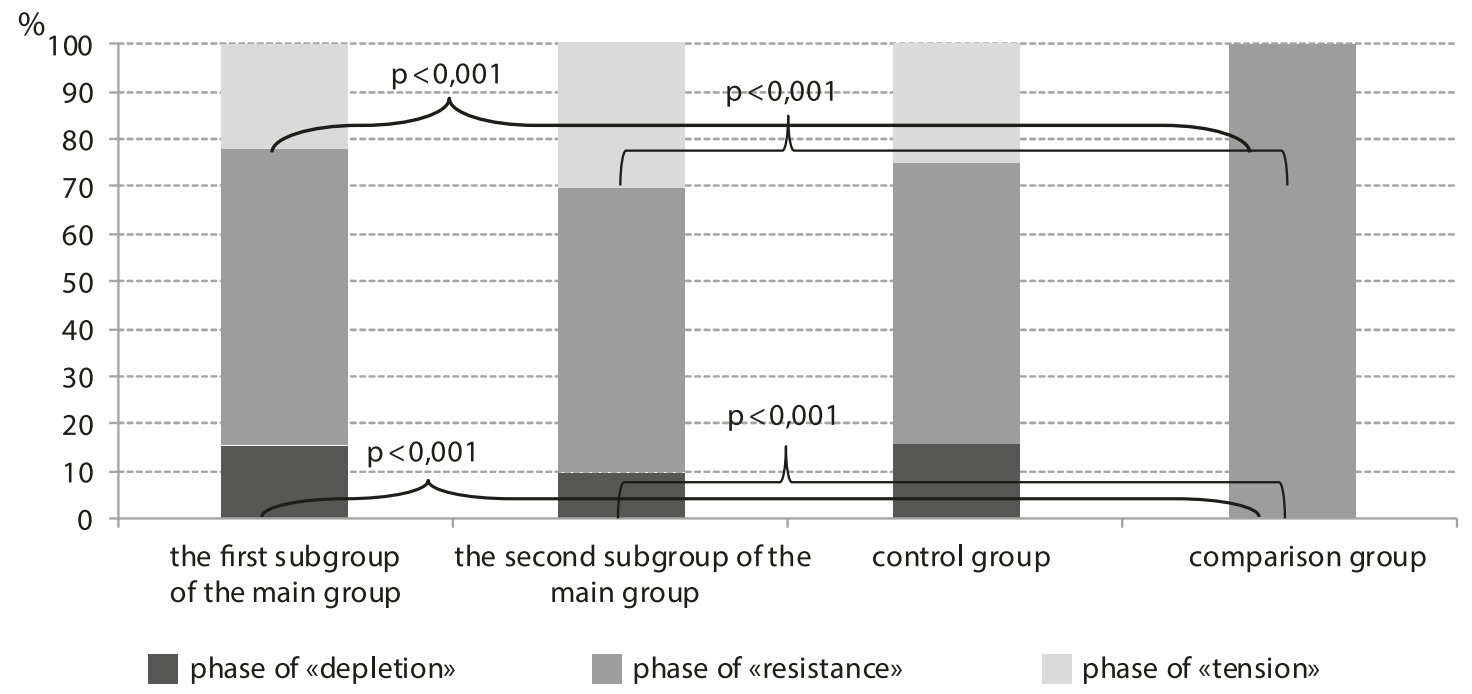

Figure 4. Structure of the occupational burnout syndrome's phases with the completed cycle of the formation of one phase among women (\%) 
A similar picture was seen in women from the control group: the percentage of those who had phase of "resistance" was $58.5 \pm 1.42 \%$, phase of "depletion" - $24.9 \pm 1.23 \%$, and phase of "tension" - $16.6 \pm 1.05 \%$. The formation of the occupational burnout syndrome's phases among women of the comparison group was absolutely different: all subjects had completely formed phase of "resistance" that can be explained by features of their labor activity, which didn't require significant emotional loads typical for female doctors of the main and control groups.

\section{Discussion}

As it is well known, the body's capabilities can compensate for those negative reactions which are a result of response to the influence of harmful occupational factors only up to a certain threshold [10]. Moreover, the nature and degree of preclinical and clinical manifestations depend on the class of working conditions and the risk category: the higher the class and degree of working conditions, the more significant the medical-social risk to the health [11]. It was also shown by analysis of the obtained results that confirmed that the share of women who had changes in pre-nosological health status increases with the unfavorable effect of the occupational factors objectively documented while assessing the working conditions of the relevant hazard class.

The mucous membrane of the oral cavity has a significant effector potential in reactions of both local and general organismic inflammatory response that arise under the influence of harmful occupational factors [5]. Buccal epitheliocytes are able to enter into active cascade and network interaction with such inducers as neutrophilic leukocytes, macrophages, T- and B-lymphocytes, eosinophils, mastocytes and dendritic cells [12]. Moreover, it is well known that there is a robust correlation dependence between the states of inflammatory and cytological status, which, in turn, causes subsequent development of various pathological processes in the body [13]. Therefore, recorded changes of the oral mucosa in the form of abnormal epithelial cell appearances is the result of the negative influence of the biological occupational factors [14]. The oral microbiocenosis is a stable ecosystem, the functioning of which can be disturbed due to the influence of anthropogenic factors of chemical nature, including occupational ones [2]. The appearance in the oral cavity of the $E$. coli bacteria group is evidence of the inhibition of nonspecific element of the immune system [8].

The results we obtained during the study are comparable to the results of other researchers, which indicate that the development of occupational burnout syndrome among doctors is typical even in the first years of work and is accompanied by decreased adaptation reserves, followed by an increase in overall morbidity [15]. The selected set of methods for pre-nosological monitoring allows the identification of the impact of different occupational factors and the formation of target risk groups for the implementation of preventive measures increasing the adaptive reserves of these critical people.

\section{Conclusions}

The professional activity of female obstetrician-gynecologists in the harmful working conditions was accompanied by decreasing adaptive reserves of their organism and significantly increased risk of occupationalrelated disease occurrence. The use of pre-nosological monitoring allows the identification of women with reduced adaptive reserves in time as well as the development and implementation of a set of purposeful preventive measures aimed at maintaining and improving health status.

\section{References:}

1. Amirov NK, Berheeva ZM, Garipova RV. [Assessment of the occupational risk of violations for health of medical workers by results of periodic medical examination]. Bulletin of Modern Clinical Medicine. 2014; 7(2): 10-14 (in Russian). https://doi.org/10.20969/VSKM.2014.7(2).10-14

2. Denisov LA, Berseneva AP, Baevsky RM, Bersenev EY, Nikitenko IV. [Pre-nosological approach to the assessment of morbidity and mortality of the population]. Hygiene and Sanitation. 2009; 6: 77-80 (in Russian).

3. Baksheva SS. [The use of noninvasive methods of donosological diagnosis to determine the anthropogenic load on the human body]. Bulletin of the Krasnoyarsk State Agrarian University. 2013; 11: 141-143 (in Russian).

4. Harrison J. Doctors health and fitness to practise: the need for a bespoke model of assessment. Occupational Medicine. 2008; 58(5): 323-327. https://doi.org/10.1093/occmed/kqn079

5. Abadzhidzhi MA, Mahrova TV, Mayanskaya IV, Zaslavskaya MI, Mayanskij AN. [Buccal epithelial cells as a tool for clinical and laboratory research]. Nizhny Novgorod Medical Journal. 2003; 3-4: 105-110 (in Russian). 
6. Aronsson G, Theorell T, Grape T, Hammarström A, Hogstedt C, Marteinsdottir I, et al. A systematic review including meta-analysis of work environment and burnout symptoms. BMC Public Health. 2017; $17: 264$. https://doi.org/10.1186/s12889-017-4153-7

7. Kolmakova TS, Belik SN, Morgul EV, Sevryukov AV. [Usage of the micronuclear test for evaluation of the effectiveness of allergy treatment in children: methodical recommendation]. Rostov on Don: Publishing house of RostSMU; 2013 (in Russian).

8. Ministry of Health of the Republic of Belarus. [Criteria and methods for determining immunological resistance of the skin and mucous membranes of the nasopharynx in assessing the health of workers when exposed to man-made chemical pollutants]. Minsk: BelSRSHI; 1999. p. 27-39 (in Russian).

9. Boyko VV. [Syndrome of emotional burnout in professional communication]. St. Petersburg: Sudarynya; 1999 (in Russian).

10. Drakopoulos SA, Theodossiou I. Workers' risk underestimation and occupational health and safety regulation. European Journal of Law and Economics. 2016; 41(3): 641-656. https://doi.org/10.1007/s10657-012-9379-3

11. Polychronakis I, Riza E, Karnaki P, Linos A. Workplace health promotion interventions concerning women workers' occupational hazards. New York: Springer; 2008.

12. Mestecky J. The common mucosal immune system and current strategies for induction of immune responses in external secretions. Journal of Clinical Immunology. 1987; 7(4): 265-276. https://doi.org/10.1007/BF00915547

13. Komali Y, Venkatesh VK, Krishnanand Komali S. Morphological assessment of oral cytological smears before and after application of toluidine blue in smokers and nonsmokers. International Journal of Oral \& Maxillofacial Pathology. 2012; 3(1): 8-14.

14. Mejer AV, Druzhinin VG, Larionov AV, Tolochko TA. [Genotoxic and cytotoxic effects in buccal epithelial cells of children from different environmental distinct regions of Kuzbass]. Cytology. 2010; 52(4): $305-310$ (in Russian).

15. Lee RT, Seo B, Hladkyj S, Lovell BL, Schwartzmann L. Correlates of physician burnout across regions and specialties: a meta-analysis. Human Resources for Health. 2013; 11: 48.

https://doi.org/10.1186/1478-4491-11-48 